EUROPEAN UNIVERSITY INSTITUTE, FLORENCE

DEPARTMENT OF LAW

EUI Working Paper LAW No. 2004/13

What is Left of the European Economic Constitution?

Christian JOERGES 
All rights reserved.

No part of this paper may be reproduced in any form without permission of the author(s)

(C) 2004 Christian Joerges

Published in Italy in November 2004

European University Institute

Badia Fiesolana

I - 50016 San Domenico (FI)

Italy

www.iue.it 


\title{
What is Left of the European Economic Constitution?*
}

\author{
Christian JoERgES \\ Bremen/Florence
}

\section{ABSTRACT}

The essay starts from the assumption that the efforts to cure Europe's democracy deficits will also have to address the social problématique of the Europeanization process. This is a challenge with new dimensions. Europe had started its integrationist path as a mere economic community. In its formative era, the constitutional perspectives of German Ordo-liberalism were attractive. In the ordo-liberal account, the European polity has a twofold structure: At supranational level, it is committed to economic rationality and a system of undistorted competition. Redistributive (social) policies could - and should - be left to the Member States. This edifice was refined in the 1970s and 80s. Monetary Union and the Stability Pact completed it. The German Constitutional Court's Maastricht judgment endorsed its constitutional validity. However, the new dynamics and the strive for an "ever closer Union" in the Maastricht Treaty has led to a strengthening of European regulatory policies and a broadening of their scope, which were incompatible with the ordo-liberal legacy. The erosion of the economic constitution has not paved the way to a cure for Europe's social deficit. Neither the Open Method of Co-ordination nor the commitment to a "social market economy" in the Constitutional Treaty nor the new "social rights" provide a conceptually sufficient and politically credible basis for this end.

Keywords: Legitimacy; open coordination; economic law; stability pact; welfare state; European Convention.

Affiliation: Christian Joerges, Professor of European Economic Law, European University Institute, Florence; email: joerges@iue.it

\footnotetext{
Elaboration of the introductory lecture of the Academy European Law - Session on European Union Law - at the European University Institute in Florence delivered on 5 July 2004. I am indebted to Marc Amstutz, Milena Büchs, Damian Chalmers, Philip Manow, John McCormick, Rainer Nickel, Tommi Ralli, Florian Rödl and Stephen Weatherill for their encouraging comments and constructive suggestions.
} 



\section{Contents}

I. Introduction: The Many Faces of an Historical Event ..................................................5

II. What is an Economic Constitution? ....................................................................................9

1. The Social Market Economy: An Economical Christian Project.............................12

2. The Economic Constitution: "Authoritarian Liberalism” Revisited? ........................ 12

3. Ordo-liberalism in the European Community: the Decoupling of Economic Integration from the Welfare State and its Social Policy........................................ 14

III. The Ambivalences of the post-1985 Developments..........................................................17

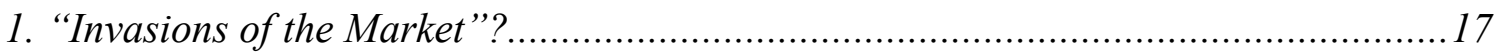

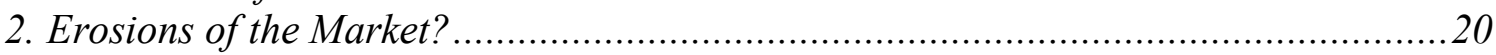

3. Rules versus Politics? Monetary Union, the Maastricht Judgment and the Stability

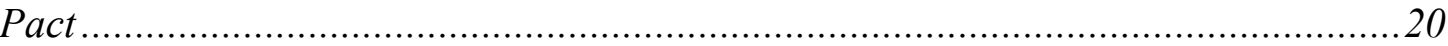

IV. Are we About to Bring the Law to Trial? Some Queries with the Open Method of Co-ordination...........................................................................................................225

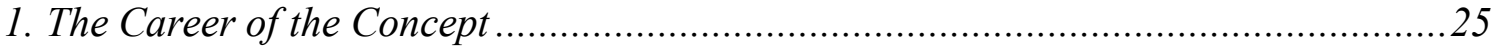

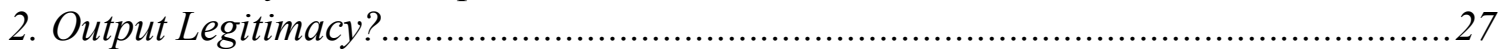

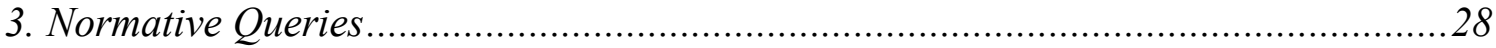

3.1. Democratic Experimentalism?..............................................................29

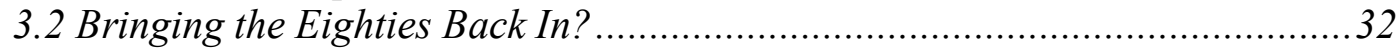

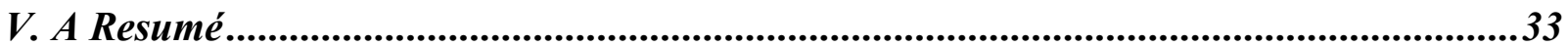

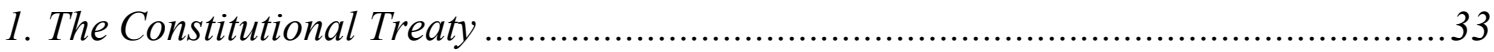

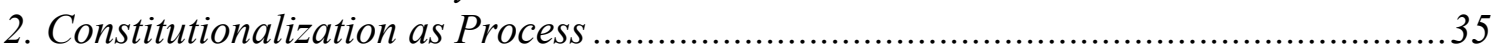





\section{Introduction: The Many Faces of an Historical Event}

"What is Left?" was the title of a series of articles in the Frankfurter Allgemeine Zeitung, which the social philosopher Stephen Lukes, then Professor at the European University Institute in Florence, had inspired after the fall of the Berlin Wall on 9 November 1989. The contributors to the series reflected on this event, and its historical dimensions and repercussions. Did the breakdown of the Soviet empire and the end of the Cold War also signal the end of the critique of capitalism and of the political left in the West? The title of the series was, indeed, a question. The authors were all from the West, all from the Left, and were concerned with the future of their political affiliations and the various facets of Social Democracy. The Frankfurter Allgemeine Zeitung appreciated these scrupulous questions and opened its Feuilleton, translating everything, without, however, finding a German equivalent for Stephen Lukes' melancholic leitmotiv.

The title of this essay insinuates that the queries raised in 1989 are still very much on the European agenda. This is certainly a discomforting message, one which is not in harmony with the recent seminal accomplishments of the integration progress, in particular, the deepened constitutionalization of the European Union and the Union's enlargement towards Eastern Europe. But it is, at the same time, an unsurprising observation. Can the welfare state survive globalisation? ${ }^{1}$ Can "the" European social model survive Europeanization? ${ }^{2}$ The intensity of the debate on these issues is an indicator of their importance and this importance is uncontested. Does this imply that the efforts to cure the "democracy deficit" of the integration project will remain deficient if they fail to overcome Europe's "social deficit"? It is one thing to agree with such a suggestion: it is quite another to identify an adequate theoretical framework in which the constitutional discourse can, and should, address it. The effort that this essay undertakes rests upon three interdependent (bundles of) premises.

The first: constitutionalism must reach down into the economic system and the social fabric of society. If it fails to do so, it loses its democratic credentials. This strong statement needs much explanation. Three references need to be given: one historical precedent is the

1 For a recent systematic overview, see St. Leibfried and M. Zürn, "The Unravelling Golden Age State", in St. Leibfried and M. Zürn (eds.), Transformations of the State?, Cambridge University Press 2005 [European Review 2005 (13) 1], available at http://www.sfb597.uni-bremen.de/transformations/.

2 Cf., among many, C. Offe, "The European model of 'social' capitalism. Can it survive European integration?" Journal of Political Philosophy 11 (2003), $437 \mathrm{ff}$. 
debate within the Staatsarechtslehre of the Weimar Republic ${ }^{3}$ Not at the core, but significant, too, were the ideas of Wirtschaftsdemokratie (economic democracy) and Sozialverfassung (social constitution) as promoted by Franz Neumann, Hugo Sinzheimer, and Ernst Fraenkel. ${ }^{4}$ All this was taken up after World War II under the new German constitution. ${ }^{5}$ Just a Sonderweg of German constitutional theory? Certainly more than that. The tensions between law and social justice and its "juridification" are of general importance. ${ }^{6}$ And to take the argument a step further into an uncharted sea: this debate is linked to the project of modernity itself: to the tension and conflict "between the project of political modernity defined as

3 Particularly well documented in English by P.C. Caldwell and W.E. Scheuerman (eds.), From Liberal Democracy to Fascism: Legal and Political Thought in the Weimar Republic, Boston 2000; A.J. Jacobsen, and B. Schlink (eds.), Weimar. A Jurisprudence of Crisis, Berkeley-Los Angeles-London 2000; J.P. McCormick (ed.), Mass Democracy and Industrial Technology. Political and Social theory from Nietzsche to Habermas, Durham, NC-London 2002.

4 See, on Franz Neumann, recently, M. Iser and D. Strecker (eds.), Kritische Theorie der Politik. Franz L. Neumann - eine Bilanz, Baden-Baden 2002. On Fraenkel, see W.E. Scheuerman, "Social Democracy and the Rule of Law: The Legacy of Ernst Fraenkel" (ibid.), $74 \mathrm{ff.}$

5 P.C. Caldwell, "Is a Social Rechtsstaat Possible? The Weimar Roots of a Bonn Controversy", (ibid., note 4), $136 \mathrm{ff}$.

6 Cf., the Special Issue of the Canadian Journal of Law and Jurisprudence on Social Democracy (Guest Editor: Colin Harvey); to cite just one contributor: R. Burchill, "The EU and European Democracy - Social Democracy or Democracy with a Social Dimension?", $185 \mathrm{ff}, 186$ argues: "In addressing the 'wider issues' of democracy, we are taken beyond the political sphere to engage with the social and economic organisation of society. Once we move in this direction, agreement about the nature, scope and content of democracy becomes very contentious. If the overall purpose of democracy is "to provide the conditions for the full and free development of the essential human capacities of all the members of the society" [referring to M Loughlin, "Rights, Democracy, and Law" in T. Campbell, K. Ewing and A. Tomkins (eds.), Sceptical Essays on Human Rights, Oxford 1992, 42 ff.]. He goes on "....[D]emocracy needs to be something more than the existence of a few basic political procedures. By bringing the idea of 'social' into the frame, we then begin to address the wider issues by incorporating the social and economic aspects of society into our understanding of democracy. However, as this involves making normative claims in relation to democracy, it is widely felt that this stretches the understanding of democracy too far". And there is even more continuity with Weimar scholarship: "Constitutionalisation" has become a quest which affects ever more spheres of "secondary" law, including private law and under the label of "societal constitutionalism". See G. Teubner, "Societal Constitutionalism. Alternatives to State-centred Constitutional Theory?", in Ch. Joerges, I.-J. Sand and G. Teubner (eds.), Transnational Governance and Constitutionalism, Oxford 2004, $3 \mathrm{ff}$. Continuity in the discussion of the tensions between the political objectives of social democracy and the rule of law in liberal democracies seems particularly relevant in the context of this paper. However, it is clear that it does not cover the relationship between constitutionalism and society comprehensively and that it fails to specify the reasons for the deepening of the interest in a "European social model".

What is true for both these traditions and the notion of an "economic constitution" applies, of course, also to "economic law". This term cannot be adequately translated into English, as neither its ordo-liberal nor its critical understanding - represented by titles such as Wirtschaftsrecht als Kritik des Privatrechts ("economic law as critique of private law”), H.-D. Assmann, G. Brüggemeier, D. Hart and Ch. Joerges, Königstein/Ts. 1980) have an equivalent in the English speaking world; cf., very briefly, Ch. Joerges, "Economic Law, the Nation-State and the Maastricht Treaty", in R. Dehousse (ed.), Europe after Maastricht: an Ever Closer Union?, Munich 1994, 29 ff., 30-32. 
collective self-determination, and economic modernity defined as the autonomous determination of the ways in which human needs are satisfied".

The second premise can be explained by a reference "Economy and Society", Max Weber's famous notion and project of a social theory which includes sociology of law. This type of a sociologically informed jurisprudence is under-represented the agenda of European constitutionalists. The law of the economy, of industrial relations, and the ever deeper involvement of the European Union with social policy ${ }^{8}$ did not, of course, go unnoticed. But these matters were handed over to the experts of the fields that were under scrutiny. ${ }^{9}$ The Theory of the European Economic Constitution to which the title of this essay alludes is a great exception. This theory is a truly constitutional response in its crafting of the interdependence of the Rechtsstaat, the ordering of the European economy, and the assignment of social policy to the nation states. In this way, the Theory of the European Economic Constitution has contributed to the decoupling (Scharpf) ${ }^{10}$ of social policy from the European project. ${ }^{11}$ This normative objection is, however, linked to a more "sociological" critique. The theory's potential to guide the European project is exhausted, and the efforts to revive it have failed or are bound to be unsuccessful.

In an important sense, however, the exhaustion of the economic constitution is a mixed blessing. To anticipate the thesis which Section IV of this essay will defend: the erosion of the economic constitution did not pave the way to "social Europe" or to the reconstruction of a European social democracy. Neither the commitments of the Constitutional Treaty to a "social market economy" nor the new social rights or the turn to "new modes of governance" are really trustworthy and highly ambivalent. In particular, the "Open Method of Co-ordination" threatens the very idea of constitutionalism, namely, the idea of law mediated, and rule-of-law

7 F. Block, Towards a New Understanding of Economic Modernity, in Ch. Joerges, B. Stråth and P. Wagner (eds.), The economy as a polity. The political construction of modern capitalism - an interdisciplinary perspective, London (GlassHouse) 2004, ch. 1 (forthcoming).

8 "Creeping Europeanization" in the analysis of C. Offe (note 2).

9 Cf., the Review Essay of J.P. McCormick, "Democratic Theory Confronts the European Union. Prospects for Constitutional and Social Democracy in a Supranational Sektoralstaat" (forthcoming in Political Theory).

10 F.W. Scharpf, "The European Social Model: Coping with the Challenges of Diversity", Journal of Common Market Studies, 40 (2002), 645 ff., at 646.

11 A political science version of this thesis is Fritz Scharpf's well-known contention that democracies which prove to be unable to resolve problems of economic and social stability risk the loss of social legitimacy [e.g., "Democratic Policy in Europe", European Law Journal 2 (1996), 136-155], a thesis closely linked to Scharpf's famous analysis of Europe's "political deficit": "The Joint-Decision Trap: Lessons from German Federalism and European Integration", Public Administration 86 (1088), 239-278 ("Die PolitikverflechtungsFalle. Europäische Integration und deutscher Föderalismus im Vergleich", Politische Vierteljahresschrift 26, 1985, 323-356); for an update, cf., "The European Social Model" (note 10) and "Problem-Solving Effectiveness and Democratic Accountability in the EU”, Ms. Cologne 2004. 


\section{Christian Joerges}

bound governance. This argument is based on a third premise which is "conservative" in that it insists that European "governance" practices must not take the rule of law lightly.

In the elaboration of this three dimensional theoretical framework, this essay will take a reconstructive approach. The following section will first point to the origins of the theory of the economic constitution, and explain its specific notion of constitutionalism (II.1). It will then deal with the transformation of this theoretical heritage in post World War II Germany into the "social market economy" (Soziale Marktwirtschaft) (II.2). The concluding part of this section will seek to explain why the theory of the economic constitution provided such an attractive design for the formative era of the European integration project. It will, however, be added that the importation of this theory into the European project came at a price. It prepared the ground for Europe's "social deficit”, which remains so difficult to overcome (II.3).

The leading proponents of this approach had fundamentally renewed their theoretical basis by the 1960 s and 1970 s, in such a way that they seemed well prepared for the new dynamics of European integration in the 1980s (Section III.1). However, the new dynamics and the striving for an "ever closer Union" in the Maastricht Treaty led to a strengthening of European regulatory policies and a broadening of their scope, both of which were no longer compatible with the traditional and the renewed theoretical design (III.2). The support of the theory of the economic constitution which the German Constitutional Court's Maastricht judgment provided has proved to be a pyrrhic victory. The political constraints which this judgment confirmed damaged the economic viability of Europe and deepened the schism between national social models striving and institutionalized Europe (Section III.3).

The turn to new modes of governance presents itself as the most important remedy, which, thanks to the European Convention, even became a candidate for constitutionalization. However, the account submitted in Section IV will not be so positive.

There is not much left of the Economic Constitution and there is not much of it which is Left, either. But, this resume is not to announce an exercise in deconstruction. Throughout the whole essay a background agenda will be pursued in each of its sections, which seek to reveal another dimension of the integration process. To indicate at least the perspective: markets, so the theory of the economic constitution argues, are not self-sustaining, they need institutional backing. Yes, but markets are social institutions which cannot be governed through some objective mechanism and do not simply respond to some functional needs - they are, in the last instance, "polities". The opening of our national economies (Volkswirtschaften) requires responses, on the one hand, to the erosion of the political powers of the nation state, and, on the 
other, to the risks of unaccountable transnational governance arrangements. It is the great merit of the theory of the European economic constitution to have addressed this challenge. Its responses, however, remained one-dimensionally restricted to an institutionalization of economic rationality criteria at transnational levels of governance. The post-national constellations in which we find ourselves require more complex and socially more sensitive responses to the tensions between the opening of formerly national economies and the prerequisites of social solidarity. Such answers are not readily available. They need to be discovered in reflective practices - and Europe's constitutionalization need, therefore, to be conceptualized as a process, in which Law has to supervise and to discipline the practices of governance.

\section{What is an Economic Constitution?}

It is - or should have become - impossible to use the term constitutional law without reflecting the theoretical yardsticks which are invoked to assign specific functions and justify specific validity claims of "constitutional" norms. It is hence insufficient to point to the supremacy doctrine, direct effect, or the resistance to change on the part of core elements of European law, to characterize them as constitutional. ${ }^{12}$ This kind of definition is particularly popular among European lawyers, because it allows them to talk about a European constitution without discussing discrepancies with the juridification of political processes, institutional states, or the democracy deficits of European governance practices. The use of the word constitution in relation to European economic law is, then, nothing spectacular. But it is also empty because such a notion does not inform us about the validity claims of the economic constitution, let alone, its (normative) legitimacy. ${ }^{13}$ This, and nothing less, is the promise and the aspiration of the theory of the economic constitution, and only because of these ambitions can it claim constitutional status.

12 See Ch. Möllers, "Verfassungsgebende Gewalt - Verfassung - Konstitutionalisierung", in A. v. Bogdandy (ed.), Europäisches Verfassungsrecht. Theoretische und dogmatische Grundlagen, Berlin-HeidelbergNewYork 2003, $1 \mathrm{ff}$.

13 "Economic constitutional law consists of the constitutional rules that deal with economic matters". This definition from J. Baquero Cruz, Between competition and free movement: the economic constitutional law of the European Community, Oxford 2002, 29 is not simply self-referential, because the author has first laid out a meta-positivist "notion of constitution" which is "inscribed within the Western legal tradition" (ibid., at 12). But it seems not sufficiently substantiated to provide a basis for determining the recognition which the internal market, European competition law and the four freedoms deserve. 
In order to understand these ambitions, we have to take a detour and a glance, first, at the origins, and, then, at the development of our notion. ${ }^{14}$ The "economic constitution" originated in the social turmoil and intellectual laboratory of Weimar - and this is so for very transparent reasons. ${ }^{15}$ It was not so absurd, and was, at any rate, a widely held view that the economic crises and social tensions of post-First World War Germany were becoming out of control and that the Republic was threatened by strong and bitter opponents both from the radical right and from the radical left. Ordo-liberalism sought a liberal answer to this crisis. This answer had to distance itself from the laissez-faire ideas which Alexander Rüstow, which

14 The literature in German is abundant, in English less so [recent analyses: D.J. Gerber "Constitutionalizing the Economy: German Neo-liberalism, Competition Law and the 'New' Europe", American Journal of Comparative Law 42 (1994), 25 ff.; W. Sauter, Competition Law and Industrial Policy in the EU, Oxford 1997, 26 ff.], comprehensively, albeit with only scarce references to the legal "branch" of Ordo-liberalism and Ordnungstheorie Ch. Mantzavinos, Individuals, Institutions, and Markets, Cambridge 2001. There seems to be little available in French (but see L. Azoulay, "L'ordre concurrentiel et le droit communautaire", in M.-A. Frison-Roche (ed.), L'ordre concurrentiel, Mélanges en l'honneur d'Antoine Pirovano, ed.), Paris 2003, $277-$ 310 .

15 In the account of J. Baquero Cruz (op. cit., note 13, at 26) the meaning that this tradition gave to the concept is "creating confusion and turning, as it were, against certain basic conceptions and functions of constitutionalism". This harsh judgement is directed only at "the original ordo-liberal version defined in The Ordo Mainfesto of 1936" (signed by Franz Böhm, Walter Eucken, Hans Großmann-Doerth), in which he finds a "strong Schmittian flavour". It is difficult to understand, however, why we should assign the status of a foundational document to the 1936 Manifesto and neglect other, often more famous, writings (see notes 18-19 below). It seems equally problematical not to take into consideration how generations of scholars have developed the theory further and adapted it to the various phases of the European integration process. J. Baquero Cruz's note made "more in passing" on the Schmittian flavour does, however, concern an interesting affinity (see note 25 below), although it is also problematical for two reasons. First, because it is for obvious historical reasons likely to evoke the wrong political and moral connotations. The Ordo-liberals were an opposition group in Nazi Germany. Their common - religious - concern over the Reichskristallnacht had brought the group together. Franz Böhm and Walter Eucken were members of the Bekennende Kirche. Some Members of the Freiburg School risked their lives in the resistance against Hitler. Großmann-Doerth, 42 years old in the Manifesto year of 1936, and drafted into the Wehrmacht in July 1939, died in 1944. Alexander Rüstow and Wilhelm Röpke had left Germany. On all this, see D. Haselbach, Autoritärer Liberalismus und Soziale Marktwirtschaft. Gesellschaft und Politik im Ordoliberalismus, Baden-Baden 1991, and, more recently, Ph. Manow, "Ordoliberalismus als ökonomische Ordnungstheologie" Leviathan 2001, 179 ff. and his unpublished Habilitationsschrift on "Social Protection and Capitalist Production. The Bismarckian Welfare State and the German Political Economy, 1880-1990", Cologne 2004, 76 ff., 93 ff.); and second, Baquero Cruz seems to misinterpret the "Schmittian flavour". The "strong state" that the Ordo-liberals asked for was certainly not a pluralist democracy (see K.W. Nörr, Die Leiden des Privatrechts. Kartelle in Deutschland von der Holzstoffkartellentscheidung bis zum Gesetz gegen Wettbewerbsbeschränkungen, Tübingen 1994, 174). But this does not mean that they were striving for the same type of "qualitatively strong" state which Carl Schmitt had called for in his famous 1932 speech ["Starker Staat und gesunde Wirtschaft. Ein Vortrag vor Wirtschaftsführern" ("A Strong State and a Healthy Economy. A Lecture for Business Leaders"), held on 23 November 1932, published, for example, in Volk und Reich. Politische Monatshefte 1933, 81 ff.]. Schmitt's strong state claimed the political primacy of politics over the economy, whereas the Ordo-liberals sought to impose a stable legal framework on the economy which the political system, for its part, was to respect (cf., R. Wiethölter, "Franz Böhm (1895 - 1977)", in B. Diestelkamp and M. Stolleis (eds.), Juristen an der Universität Frankfurt a.M., Baden-Baden 1989, 208 ff. - No economic theory remains the same over decades, however. On the development of the economic theory side of Ordo-liberalism cf., very lucidly, for example, Ch. Mantzavinos, Wettbewerbstheorie. Eine kritische Auseinandersetzung, Berlin 1993 and more recently his Individuals, Institutions, and Markets, Cambridge 2001. 
were discredited as "paleo-liberalism". ${ }^{16}$ Two famous manifestos, often characterized as the foundational manifestos of Ordo-liberalism, were published at the peak of the crisis in 1932: Walter Eucken's "staatliche Strukturwandlungen und die Krise des Kapitalismus", ${ }^{17}$ and Alexander Rüstow's "Interessenpolitik oder Staatspolitik". ${ }^{18}$ Other subsequently famous protagonists followed suit in the same year: ${ }^{19}$ Franz Böhm's seminal monograph on Wettbewerb und Monopolkampf followed only one year later. ${ }^{20}$ The answer was liberal in its rejection of the two state-focused contemporary competitors, the Historic School of Economics on the one side, and socialist ideas as propagated by the labour movement on the other. ${ }^{21}$ It was post-laissez-faire in that it assigned the task of ensuring the ordo of the economic sphere to the state. Walter Röpke used the oxymoron "liberal interventionism" to characterize this function. ${ }^{22}$ The old paleo-liberal Nachtwächterstaat (laisser-faire state) was to be replaced by a "strong state". ${ }^{23}$ And the intellectual primus of the constitutionalist Weimar Left immediately understood this: Ordo-liberalism is an authoritarian liberalism, Hermann Heller responded. ${ }^{24}$ His response hit a nerve. Only recently, William E. Scheuerman has taken up Heller's line of argument and applied it to the institutional suggestions of the master-mind of the second generation of Ordo-liberals, the paleo-liberal economist and social philosopher Friedrich von Hayek. $^{25}$

16 "Paläoliberalismus, Kollektivismus und Neoliberalismus in der Wirtschafts- und Sozialordnung", in K. Förster (ed.), Christentum und Liberalismus - Studien und Berichte der Katholischen Akademie in Bayern, Vol. 13, 149-178; see, also, his "Interessenpolitik oder Staatspolitik?" in Der Deutsche Volkswirt 6 (1932), 169 ff.; idem, "Freie Wirtschaft - starker Staat", in Franz Bosse (ed.), Deutschland und die Weltkrise (Schriften des Vereins für Socialpolitik 187). Munich 1932, $62-69$.

17 In Weltwirtschaftkliches Archiv 36, 297-321, reprinted in Ordo 48 (1997), 5-25.

18 In Der Deutsche Volkswirt 6 (cited from the reprint in W. Engels and H. Froels (eds.), Querschnitte, Düsseldorf 1986, 66-71.

19 A. Müller-Armack, Entwicklungsgesetze des Kapitalismus. Ökonomische, geschichtstheoretische und soziologische Studien zur modernen Wirtschaftsverfassung, Berlin 1932. - On Müller-Armack's biography and work, see D. Haselbach, Autoritärer Liberalismus und Soziale Marktwirtschaft. Gesellschaft und Politik im Ordoliberalismus, Baden-Baden 1991, 117 ff.

20 Berlin 1933.

21 W. Abelshauser, Kulturkampf. Der deutsche Weg in die neue Wirtschaft und die amerikanische Herausforderung, Berlin 2003, $158 \mathrm{ff}$.

22 See W. Röpke, German Commercial Policy, London 1934, 40 ff.; see, also, Die Lehre von der Wirtschaft, Vienna 1937; on Röpke, cf., M. Glasmann, op. cit., 52 ff.

23 A. Rüstow in 1932 before the Verein für Socialpolitik: "Einen starken Staat, einen Staat oberhalb der Wirtschaft, da, wo er hingehört" ("a strong state, a state situated at a level above the economy, as appropriate"), note 16 above; cf., W. Abelshauser, op. cit. (note 21) 159.

24 H. Heller, "Autoritärer Liberalismus", Die Neue Rundschau 44 (1933), 289 ff.

25 W.E. Scheuerman, "The Unholy Alliance of Carl Schmitt and Friedrich A. Hayek", Constellations 4 (1997), $172 \mathrm{ff}$.; see note 57 infra. 


\section{The Social Market Economy: An Economical Christian Project}

But this is an anticipation of some of the aspects and developments to which we will have to return. ${ }^{26}$ More important for the impact of Ordo-liberalism in post-war Germany is another dimension, which Philip Manow has carved out in a series of fascinating studies. ${ }^{27}$ The social question which generated so much unrest in early capitalism was a challenge to the Christian churches, and the institutional varieties of European welfarism mirrored religious affinities. This is not major news concerning political Catholicism. But the story which Manow recounts about the importance of social Protestantism is new, ${ }^{28}$ and this is of particular importance for the students of the "economic constitution". "Ordo" is a Catholic notion. Yet, the Ordo-liberals who embraced it - Walter Eucken, Alexander Rüstow, Wilhelm Röpke - were all strongly linked to Protestantism. ${ }^{29}$ What both the Protestants and the Catholics sought was a third way between capitalism and socialism - and this alliance was the underpinning of Germany's postwar social market economy; this was their ecumenical project and became the common project of the Protestants and the Catholics in the Christian Democratic Union.

\section{The Economic Constitution: “Authoritarian Liberalism” Revisited?}

The alliance of churches, political Protestantism and Catholicism in the early post-war years extended itself to the trade unions - Germany's social market economy was their common project and became a political, social and economic success. ${ }^{30}$ But this alliance was not to last for long. Germany had neither overcome secularization nor the political factioning which it had cultivated ever since the Kaiserreich. As Manow documents, the heritage of mistrust of Social

26 Infra Section III.

27 Ph. Manow, "Modell Deutschland as an interdenominational compromise", Minda De Gunzburg Centre for European Studies, Working Paper 003/2001; idem, "Ordoliberalismus als ökonomische Ordnungstheologie" Leviathan 2001, 179 ff.; idem, “"The Good, the Bad, and the Ugly'. Esping-Anderson's Sozialstaatstypologie und die konfessionellen wurzeln des westlichen Wohlfahrtsstaats", Kölner Zeitschrift für Soziologie und Sozialpsychologie 54 (2002), 203 ff. (English version at http://www.mpi-fgkoeln.mpg.de/people/pm/download_de.html) and his unpublished Habilitationsschrift on "Social Protection and Capitalist Production. The Bismarckian Welfare State and the German Political Economy, 1880-1990", Cologne 2004.

28 "New" is, of course, a relative concept. In the core Chapter 3.5 on "Social Protestantism and the Redefinition of Social Reforms", Manow points not just to primary sources but also to an impressive range of historical studies.

29 Ph. Manow, "Social Protection" (op. cit.), at 76, note 5. So was the great spokesman of the Social market economy in the Early Bonn Republic, Alfred Müller-Armack; on his religious background, see D. Haselbach, Autoritärer Liberalismus (note 19), 119.

30 For a concise analysis, see M. Glasman, Unnecessary Suffering. Managing Market Utopia, London-New York 1996, especially at $50 \mathrm{ff}$. (on Ordo-liberalism) and $56 \mathrm{ff}$. (on post-war Germany). 
Catholicism against economic liberalism resurfaced, and the old alliances between Catholicism, economic corporatism and Bismarckian welfarism were rebuilt. ${ }^{31}$

The Protestant Ordo-liberals did not appreciate this restoration of patterns which looked all too similar to what they had tried to overcome back in the $1920 \mathrm{~s}$. And now, in the new Bonn Republic, they had another prestigious standing. The group had grown and its views dominated a good deal of academic life, public opinion, and the officious communications of the Christian Democratic government. Confidently and coherently, Ordo-liberalism revitalized its programme. A core element of its constitutional messages and perspectives was the theory of the "economic constitution", the thesis that the constitution should respect the interdependence of a system of undistorted competition, individual freedoms and the rule of law - and protect this precious balance against discretionary political influence. ${ }^{32}$

The return of political Catholicism and Ordo-liberalism to their distinct routes/paths renewed an old schism - as well as other historical controversies. In his studies on the history of German private law in the Weimar and Bonn Republic, Knut Wolfgang Nörr ${ }^{33}$ distinguishes two concepts in the (German) history of economic law: the "organized economy" and the "social market economy". He downplays the tensions within the second camp, but rightly underlines that the co-existence of the "organized economy" tradition, on the one hand, and Ordo-liberalism, on the other, amounted to the institutionalization of a paradox: Germany cultivated both the ordo-liberal credo and its concepts while the majority of its Staatsrechslehrer (professors of constitutional and administrative law) did not take the ordoliberal "constitutionalization" of the economy seriously. ${ }^{34}$ Nörr accordingly diagnoses "a basic phenomenon in the history of the emergence of the Bonn Republic ... [a] dual line, in economic policy and economic constitutional law".35

31 Ph. Manow, "Social Protection", 84 ff.; W. Abelshauser, Kulturkampf (note 23), 93 ff.

32 Cf., out of a rich literature, for example, G. Brüggemeier, Entwicklung des Rechts im organisierten Kapitalismus, Vol. 2, Frankfurt a.M. 1979, 322 ff. (the reasons for the benign neglect of this book by Germany's Rechtswissenschaft are one of its well-kept secrets); F. Kübler, "Wirtschaftsrecht in der Bundesrepublik - Versuch einer wissenschaftshistorischen Bestandsaufnahme", in D. Simon (ed.), Rechtswissenschaft in der Bonner Republik, Frankfurt a.M. 1994, 364 ff.

33 Die Republik der Wirtschaft. Teil I: Von der Besatzungszeit bis zur Großen Koalition, Tübingen 1999, 5 ff.; cf., earlier his Zwischen den Mühlsteinen. Eine Privatrechtsgeschichte der Weimarer Republik, Tübingen 1988, and Die Leiden des Privatrechts. Kartelle in Deutschland von der Holzstoffkartellentscheidung bis zum Gesetz gegen Wettbewerbsbeschränkungen, Tübingen 1994.

34 And vice versa: The Ordo-liberals dominated economic law and private law. They remained unimpressed by mainstream Staatsrechtslehre; even the explicit rejection of the theory of the economic constitution by the Bundesverfassungsgericht (Entscheidungen des Bundesverfassungsgerichts 7, 377 (1958) - Investment aids) did not irritate them.

35 K.W. Nörr, Die Republik der Wirtschaft (note 33), 84 (my translation). 
Paradox or List der Vernunft? Yet, the dual structure which Nörr finds so contradictory in theory proved to be very successful in practice. The social dimension of Germany's post-war market economy survived and flourished. ${ }^{36}$ This is well-known and explains why "a highly competitive social market economy" figures now in Article I-3 of the Constitutional Treaty, and also figures as one of the objectives of the European Union. ${ }^{37}$ Its hopes for a prestabilized harmony between economic competitiveness and social solidarity are well-founded. In Manow's account of the German example, the success of the social market economy resulted from the inability of both laissez-faire and authoritarian liberalism to determine the policies of the Bonn Republic. Instead, Germany institutionalized "a system of decentralized and functional interventionism". ${ }^{38}$ In Glasman's brilliant summary: "No one 'designed' post-war Germany, it was hewn out of far more durable and sophisticated moral and ethical materials than those provided by economic theory or any other social science methodology". 39

\section{Ordo-liberalism in the European Community: the Decoupling of Economic Integration}

\section{from the Welfare State and its Social Policy}

The real existing compromise, a Wirtschaftsverfassung with strong corporatist elements, the economic democracy aspirations in political Catholicism and the reconstruction of the Bismarckian welfare state under the Catholic Chancellor Adenauer were anathema to the leading Ordo-liberals. They saw Germany again "on the road to serfdom". And, indeed, their institutional agenda, on which the quest for strong bodies dedicated to the defence of free competition and insulated from both the pluralism of interest groups and governmental political insinuations ranked so highly, was very often frustrated in Germany's Verhandlungsdemokratie. ${ }^{40}$ Thus, it is small wonder that they embraced the integration project, supporting its establishment with all their considerable energy - and crafted their views into this emerging institution.

36 W. Abelshauser, Die Langen Fünfziger Jahre. Wirtschaft und Gesellschaft in Deutschland 1949 - 1966 , Frankfurt a.M. 1987.

37 See Ch. Joerges and F. Rödl, “The 'Social Market Economy’ as Europe’s Social Model?”, EUI Working Paper Law No. 2004-8 (https://www.iue.it.UB/law/04-8.pdf) on the Draft Treaty establishing a Constitution for Europe, CONV 850/03, Brussels, 18 July 2003; the amendment of Article I-3 by the EU Intergovernmental Conference on 22 June 2004 (Annex 3, doc. 82/04, is accessible at http://www.statewatch.org/news/2004/jun/constitution-amendments-june22.pdf

38 Ibid., Ch. 3.6, at 96.

39 Op. cit., 55.

40 The Kartellgesetz was enacted only in 1957 under the chancellorship of Konrad Adenauer with Ludwig Erhard, the strongest political ally of the Ordo-liberals, acting as its promotor; it was presented as "the Basic Law of the Social Market Economy", but did, by no means, realize the ordo-liberal ideals comprehensively. See the reconstruction of the whole process in G. Brüggemeier, Entwicklung des Rechts im organisierten Kapitalismus, Vol. 2, Frankfurt a.M. 1979, 383 ff. 
The formative phase of the European Economic Community has often been recounted in many languages and in various disciplines - especially by lawyers, political scientists, and historians. ${ }^{41}$ The history of the European economic constitution is well documented. ${ }^{42}$ I myself have published short versions of it on many occasions. ${ }^{43}$ Let me repeat this much here: the affinities between Ordo-liberalism and the integration project of 1958 were manifold - for a series of reasons. As a concept, Ordo-liberalism appeared particularly appropriate for the legitimization and orientation of the integration project. The freedoms guaranteed in the EEC Treaty, the opening up of national economies, and anti-discrimination rules and the commitment to a system of undistorted competition, were interpreted as a "decision" which supported an economic constitution that matched the ordo-liberal conceptions of the

41 Masterly by J.H.H. Weiler for law [see his "Transformation of Europe", Yale L.J. 100 (1991), 2 ff.; The Constitution of Europe. "Do the new Clothes have an Emperor?", Cambridge 1999, 10 ff.], by A. Moravscik for political science (The Choice for Europe. Social Purpose/State Power from Messina to Maastricht, Ithaca, NY 1998, 86 ff., for history by Alan S. Milward (The European Rescue of the Nation-State, $2^{\text {nd }}$ ed., LondonNew York 1999). Interestingly enough, legal history has treated Europe with un-benign neglect, and equally revealing, none of the master tales cited takes note of Ordo-liberalism and its "economic constitution" (for an explanation, see note 42).

42 M.E. Streit and W. Mussler, "The Economic Constitution of the European Community. From 'Rome' to 'Maastricht'", European Law Journal 1 (1995), 5-30; W. Mussler, Die Wirtschaftsverfassung der Europäischen Gemeinschaft im Wandel. Von Rom nach Maastricht, Baden-Baden 1998; P. Behrens, "Die Wirtschaftsverfassung der Europäischen Gemeinschaft", in G. Brüggemeier (ed.), Verfassungen für ein ziviles Europa, Baden-Baden 1994, 73-90; for a recent summary, see A. Hatje, "Wirtschaftsverfassung", in A. v. Bogdandy (ed.), Europäisches Verfassungsrecht., op. cit. (note 12), , 683 ff. - Valuable reconstructions in English include W. Sauter, Competition Law and Industrial Policy in the EU, Oxford 1997, 26 ff.; D.J. Gerber, "Constitutionalizing the Economy: German Neo-liberalism, Competition Law and the 'New' Europe", American Journal of Comparative Law 42 (1994), 25 ff. - "But how does all that relate to the real World?", Damian Chalmers (London) commented: "One point I have always thought is that France, Belgium, Italy were unconcerned by Ordo-liberalism, because of Article 86 (ex Article 90 EC) which they saw as a derogation from its structures (particularly the seocnd paragraph) for all their public sector. Of course, that interpretation was shattered by Höfner, but a plausible interpretation of the first 15 years of integration was that it did follow the French model. None of the Treaty provisions were directly effective. Agriculture, external commercial policy, transport, coal and steel - huge parts of the trading regimes of the 6 - all proceeded on legislative harmonisation. It was only for a period from the mid 1970s to the mid 1990s, I would argue that an ordoliberal model- with the development of Article $30 \mathrm{EC}$ and Article $86 \mathrm{EC}$ - began to get hegemony. Of course, during that period there was only limited harmonisation. Moreover, in the late 1970s, it was offset by substantial legislation in the labour and environmental law fields. My point is that there have been competing visions of the EC Treaty which have swapped predominance at different times". A good question which can be complemented: if Ordo-liberalism is so important, why did hardly anyone outside Germany and hardly any political scientist become aware this? [Philip Manow, in the work cited in notes 15 and 27, is not covering Europe; but, see recently, Ph. Manow, A. Schäfer and H. Zorn, "European Social Policy and Europe's Center of Gravity, 1957-2003", Cologne 2004; see, also, Ph. Genschel, "Markt und Staat in Europa", Politische Vierteljahresschrift 39 (1998), 55 ff.]. The easy answer would be: so few people read German. A more complex answer is: political scientists do not take normative theories seriously enough. Ordo-liberalism itself, however, was always unimpressed by such benign neglect. After all, in Germany's advisory boards and institutions, lawyers and economists rank higher than political scientists. What is true for German economists working and advising in the ordo-liberal tradition is, of course, not true for economists in general. Important books such as that of M. Motta, CompetitionPolicy. Theory and Practice, Cambridge 2004, make no mention of the first or second or third generation of Ordo-liberals, nor of the legal or of the economic proponents.

43 Ever since "Markt ohne Staat" [The Market without the State? The 'Economic Constitution' of the European Community and the Rebirth of Regulatory Politics, European Integration online Papers (EIoP) Vol. 1 (1997) No 19; http://eiop.or.at/eiop/texte/1997-019a.htm]. 
framework conditions for a market economic system (at least to the degree that the many departures from the system might be classified as exceptions, and a blind eye could be (had to be!) turned to the original sin of the Common Agricultural Policy. The fact that Europe had started its integrationist path as a mere economic community lent plausibility to ordo-liberal arguments - and even required them: in the ordo-liberal account, the Community acquired a legitimacy of its own by interpreting its pertinent provisions as prescribing a law-based order committed to guaranteeing economic freedoms and protecting competition by supranational institutions. This legitimacy was independent of the state's democratic constitutional institutions. By the same token, it imposed limits upon the Community: discretionary economic policies seemed illegitimate and unlawful. ${ }^{44}$

Thus, the prospects for institutionalizing an ordo-liberal style economic constitution looked bright. But what about Germany's social market economy? In one of his recent pertinent analyses, F.W. Scharpf hypothesises about "the road not taken" back in 1950s. "Where would we now be", he asks, "if, in the 1956 negotiations leading to the Treaties of Rome and the creation of the EEC, the French (Socialist) Prime Minister Guy Mollet had had his way? Mollet, supported by French industry, had tried to make the harmonization of social regulations and fiscal burdens a precondition for the integration of industrial markets. Could attempts to harmonize social policies have succeeded or would they have blocked European integration altogether?" ${ }^{45}$ An interesting question, but, as Scharpf himself adds, an unanswerable one.

We can only know what was actually accomplished, namely, the "decoupling" of the social dimension from the institutionalization of the Europeanized "system of undistorted competition". This was quite to the liking of the Ordo-liberals. In their view, the European level of governance could not, and, indeed, should not, be burdened with political tasks that required the legitimation provided by the institutions of constitutional democracies. Regardless of one's affinity for the argument, it is coherent and compatible with the institutional order of the European Economic Community as it was originally conceived. ${ }^{46}$ The ordo-liberal

44 Significant, here, is A. Müller-Armack, "Die Wirtschaftsordnung des Gemeinsamen Marktes", in Wirtschaftsordnung und Wirtschaftspolitik, Freiburg i.Br. 1966, 401 ff. For a topical restatement, see J. Drexl, "Wettbewerbsverfassung", in A. v. Bogdandy, op. cit. (note 12), 747-802.

45 F.W. Scharpf, "The European Social Model: Coping with the Challenges of Diversity", Journal of Common Market Studies, 40 (2002), 645-670, at 645 ff.; see, also, Ph. Manow, A. Schäfer and H. Zorn, "European Social Policy and Europe's Centre of Gravity, 1957-2003" (note 42), 16 ff., and their reference to A. Milward, The European Rescue (note 41), 213 ff.

46 E.-J. Mestmäcker is the uncontested and outstanding intellectual head of the ordo-liberal tradition. He has recently published his most important essays on the constitutionalization of the economy in the EU Wirtschaft 
European polity has a twofold structure: at supranational level, it is committed to economic rationality and a system of undistorted competition. At national level, re-distributive (social) policies may be pursued and developed further.

To summarize: Europe was constituted as a dual polity. Its "economic constitution" was un-political in the sense that it was not subject to political interventions. This was its constitutional-supranational raison d'être. Social policy was treated as a categorically distinct subject. It was a/the? domain of political legislation and, thus, had to remain national. The social embeddedness of the market could, and should, be accomplished by the Member States in differentiated ways - and, for a decade or so, the balance seemed stable. ${ }^{47}$

\section{The Ambivalences of the post-1985 Developments}

The Delors Commission's "White Paper on Completion of the Internal Market" of $1985^{48}$ is widely, and with good reason, perceived as a turning point and breakthrough. After years of stagnation, the integration project developed a new dynamic - thanks to the well-chosen focus of all political energies. The evaluations of the Commission's initiative and of the processes it triggered are, of course, controversial. The protagonists of a European "economic constitution" responded very positively at first (1). However, the Maastricht Treaty of 1992, which was to transform the Community into an "ever closer Union", met with strong critique precisely because of the broadening of the European ambitions (2). Monetary Union, as agreed upon in Maastricht and then interpreted affirmatively by the German Constitutional Court, opened up yet another page (3).

\section{1. "Invasions of the Market"?}

The Commission's Internal Market initiative could be interpreted as an effort to strengthen and prioritize the institutionalization of economic rationality in the integration project. ${ }^{49}$ This interpretation was, of course, shared and promoted by observers committed to the ordo-liberal

und Verfassung in der Europäischen Union. Beiträge zu Recht, Theorie und Politik der europäischen Integration, Baden-Baden 2003. The time span ranges from 1965 to 2001. All the stages of the integration process are considered and all grand issues discussed. Less impressive in terms of theoretical grounding, however, is the new edition of his Europäisches Wettbewerbsrecht, Munich 1974: E.-J. Mestmacker and H. Schweitzer, Europäisches Wettbewerbsrecht, $2^{\text {nd }}$ ed., Munich 2004.

47 It may be worth noting that the whole construct has structural affinities, or is at least compatible with, J.H.H. Weiler's analysis of the co-existence of, and interdependence between, legal supranationalism and political intergovernmentalism in the EEC (see note 41 above) and pathbreaking "The Community system: the dual character of supranationalism", Yearbook of European Law 1 (1981), 257 ff.

48 Commission of the EC, "Commission White Paper to the European Council on Completion of the Internal Market”, $\operatorname{COM}(85) 310$ final of 14 June 1985.

49 Ch. Joerges, "Economic Law, the Nation-State and the Maastricht Treaty" (note 6), $37 \mathrm{ff}$. 
tradition. The reasons were explained in pertinent publications of ordo-liberal strongholds, such as the Advisory Board of the German Ministry of the Economics ${ }^{50}$ and the Monopolies Commission. ${ }^{51}$

The White Paper had presented its rejection of traditional harmonization policies as a consequence of the - at the time already legendary - Cassis de Dijon judgment, ${ }^{52}$ and the new emphasis on the principle of mutual recognition. In conjunction with the strengthening of the four freedoms, this legal background could be interpreted as providing a framework which would further processes of regulatory competition and hence expose national legislation to economic rationality tests. The ECJ's readiness to supervise national legislation under Article 30 (now 28) was complemented by new developments in competition law and policy. The attention shifted from market failures to regulatory failures, from the control of the anticompetitive practices of private actors to anti-competitive regulation and state aid. And from such premises, the plea for de-regulation and privatization followed with a compelling logic.

How did this re-orientation fit into the ordo-liberal economic constitution? It did not fit into it at all. But traditional Ordo-liberalism had already been thoroughly revised by its leading exponents in the late 60s. Their theoretical allegiance shifted from Walter Eucken to Friedrich A. von Hayek. The latter's "Wettbewerb als Entdeckungsverfahren"53 became the new manifesto and credo of a new generation of scholars working in the ordo-liberal tradition. ${ }^{54}$ The legal and policy implications of the revised theoretical framework were spelled out in great detail, first at national, but soon also at European level. However, these implications cannot be dealt with here. The second generation is, at any rate, in one important sense, faithful to the ordo-liberal tradition. The framework within which the integration project is supposed to develop further is un-political in that it is not subjected to political debate or deliberation. This framework again seeks to institutionalize economic liberties and economic rationality. It does

50 Wissenschaftlicher Beirat beim Bundesministerium für Wirtschaft, Stellungnahme zum Weißbuch der EGKommission über den Binnenmarkt (Schriften-Reihe 51), Bonn 1986.

51 Monopolkommission, “Achtes Hauptgutachten der Monopolkommission 1988/1989”, BT.-Drucksache $11 / 7582$ of 16 . July 1990,401

52 Case 120/78, ECR [1979] 649 - Cassis de Dijon.

53 (Competition as discovery procedure) Kiel 1968, reprinted in F.A. von Hayek, Freiburger Studien. Gesammelte Aufsätze, Tübingen 1969, 249-265.

54 The leading economist of the Freiburg school in that period was Erich Hoppmann. The most important and fascinating among the many lawyers is Ernst-Joachim Mestmäcker, a disciple of Franz Böhm (see notes 17, 48); also noteworthy in the present context is his submission to the European Convention: see the "Report to the European Convention on Economic Liberties", submitted by E.-J. Mestmäcker on 29 October 2002, which is available on the Convention Website (but did apparently not come to the attention of the Working Group VI on Economic Governance/Ordnungspolitik; see Section V.1 below). 
so more flexibly, but also more comprehensively than was originally envisaged by the ordoliberal school. It therefore deserves to be called an "economic constitution". 55

The hopes that leading exponents of the school articulated corresponded to the expectations that many critics had retained of the new orientation of the integration project. This schism between proponents and opponents forms part of a wider debate concerning the benefits and the costs of market governance. ${ }^{56}$ This debate is, of course, relevant for an assessment of the 1992 project. But it is not "directly applicable", simply because the implementation of this project disappointed the hopes of its proponents as much as it did not confirm the anxieties of its critics. What had started out as a collective effort to strengthen Europe's competitiveness and accomplish this objective through new (de-regulatory) strategies soon led to the entanglement of the EU in ever more policy fields and the development of ever more sophisticated regulatory machinery. ${ }^{57}$ It was, in particular, the concern of the European legislation and the Commission with "social regulation" (health and safety of consumers and workers, and environmental protection) which proved to be irrefutable. The weight and dynamics of these policy fields had been thoroughly underestimated by the proponents of the "economic constitution". 58

55 The turn from Walter Eucken to Friedrich A. von Hayek, and, in particular, the shift of emphasis from private to public distortions of competition affects the role of the state and state institutions. W.E. Scheuerman argues in a recent essay [Carl Schmitt and Friedrich A. Hayek, Constellations 4 (1997), $172 \mathrm{ff}$.], that the differences are not as significant as most observers assume. Indeed, von Hayek shared the ordo-liberal, and, for that matter, the Schmittian mistrust in the institutions of pluralist polities and their performance. But this convergence in the analysis does not extend to the consequence. Both may share the view that welfare interventionism leads into a "qantitatively" strong state (see C. Schmitt, note 17 supra). But Hayek certainly did not opt for the "qualitatively" strong state Carl Schmitt welcomed after 1933. This is not what Scheuerman insinuates. He is instead concerned with the chain of events that a radical dismantling of the welfare state, and the social and political risks of von Hayek's "curious institutional proposal" in Law, Legislation and Liberty (Scheuerman is referring to vol. 3, Chicago, Ill. 1979, 113) entails.

56 For a recent summary of the "case against the market, see S. Lukes, "Invasions of the Market", in R. Dworkin et al. (eds.), From Liberal Values to Democratic Transition: Essays in Honor of János Kis, Budapest-New York 2004, Ch. 4.

57 For a comprehensive account, see V. Eichener, Entscheidungsprozesse in der regulativen Politik der Europäischen Union, Opladen, 1997.

58 "Underestimated" is an empirical concept and hence not a sufficient basis for an evaluation of the neo-ordoliberal agenda. It would also be too simplistic to suggest that economic theories might in principle be incapable of addressing and dealing adequately with the problems of the "risk society" (cf., K.-H. Ladeur, Negative Freiheitsrechte und gesellschaftliche Selbstorganisation, Tübingen 2000, especially at $171 \mathrm{ff}$.; A. Arcuri, "The Case for a Procedural Version of the Precautionary Principle Erring on the Side of Environmental Preservation", in D. Mortimor (ed.) Frontiers on Regulation and Liability, Aldershot: Ashgate (forthcoming). What remains true, however, is that the protagonists of the "economic constitution" have remained silent and thereby contributed to the devaluation of their approach. 


\section{Erosions of the Market?}

The praise of the Internal Market Programme was not to last long: the preparation and adoption of the Maastricht Treaty in 1992, widely perceived as a deepening and consolidation of the integration project, met with fierce criticism. ${ }^{59}$ The reasons are manifold and - within the (neo)-ordo-liberal theoretical framework - are comprehensible and conclusive. How can one continue to assign a constitutive function to the "system of undistorted competition", when the promotion of that system is only one among many other competing objectives, and its relative weight has to be determined in political processes? ${ }^{60}$ How can one reconcile the commitment to competition as the discovery procedure in economic affairs with the acknowledgement of industrial policy as a constitutionally legitimated concern? The Maastricht Treaty was the end of the "economic constitution". From then onwards, the ordo-liberal school redefined itself as an oppositional movement. ${ }^{61}$ This is not to say that its adherents would have given up their cause. Quite to the contrary. They continued to develop the approach further and to explore all the possibilities of strengthening its (now relative) weight and impact. ${ }^{62}$ The turn was one from self-confident identification with the integration project to a critique of its course.

\section{Rules versus Politics? Monetary Union, the Maastricht Judgment and the Stability Pact}

A grand opportunity to promote the ordo-liberal cause seemed to arise in the context of the objections against the Maastricht Treaty, which were brought to the Constitutional Court in Germany (Bundesverfassungsgericht). ${ }^{63}$ Their legal framing was interesting, if not elegant, and fits well into the first set of premises named in the Introduction: ${ }^{64}$ the competences of the European Community, now the European Union, are enumerated and thus limited. They were, nevertheless, considerable and entailed, so the plaintiff argued, a disempowerment of the

59 See W. Mussler, op. cit (note 42), 166 ff.; M. Streit and W. Mussler, "The Economic Constitution ..." (note 42).; P. Behrens, "Die Wirtschaftsverfassung der Europäischen Gemeinschaft", in G. Brüggemeier, op. cit. (note 41), 73 ff.; W. Mussler, Die Wirtschaftsverfassung der Europäischen Gemeinschaft im Wandel. Von Rom nach Maastricht, 1998, 166 ff.; most elegantly, E.-J. Mestmäcker, "On the Legitimacy of European Law" (1993), reprinted in idem (note 46), $133 \mathrm{ff}$.

60 See Article 2 ad 3 (g) of the Treaty as amended by G (2) and (3) TEU.

61 See, particularly clearly, M.E. Streit and W. Mussler; P. Behrens (as cited in note 59).

62 P. Behrens, "Das wirtschaftsverfassungsrechtliche Profil des Konventsentwurfs eines Vertrags über eine Verfassung für Europa", forthcoming in Festschrift Ulrich Immenga 2004, is somewhat more cautious with the tone of his assessment of the Convention's Draft Constitution than he was with the Maaastricht Treaty (note 61 above). But the gist of the argument is the same. The multiplicity of constitutional commitments read in conjunction with the consistency postulate of Article III-1 renders the weight of the system of undistorted competition indeterminate.

63 Judgment on the Maastricht Treaty of 12 October 1993, Entscheidungen des Bundesverfassungsgerichts 89, 155, [1994] 1 CMLR 57.

64 Text accompanying notes $2 \mathrm{ff}$. 
nation state. Was such a disempowered state still a democratic constitutional state under its own constitution? In its response to this query, the Bundesverfassungsgericht promised to defend Germany's constitutional democracy against the erosion of ever more statehood. But the judgment ended up legalising European integration, confirming the constitutional legitimacy of ordo-liberal institutional ideas and curtailing the control that Member States had over their economies.

How was this achieved and why did hardly anybody notice it? The essential paradox in the Court's reasoning is readily apparent. True, the Bundesverfassungsgericht called it a constitutional "must" that the German Parliament retained "essential" competencies. But then the Court took an argumentative turn which was, in its substance, strictly ordo-liberal: economic integration was qualified as a non-political phenomenon occurring autonomously outside the Member States. All Monetary Union needed was a functional legitimacy based upon the institutionally guarantied commitment to price stability and provisions against excessive fiscal deficits. With such an institutional design, the Court concluded, economic integration would not be exposed to further questioning of its democratic legitimacy. To put it slightly differently: Europe could remain a "market without a state" while its sub-units, once called the "Masters of the Treaties" (Herren der Verträge) would be downgraded to "states without markets". 65

This reading is obviously inspired by the interpretative framework used in this essay. Outside Germany (and also inside Germany in the public law factions of European scholarship), the paradoxical side of the Court's argument went unnoticed. Instead, the Bundesverfassungsgericht's defence of nation state democracies was blamed as echoing Schmittian ideas. ${ }^{66}$ Even if this were so, the point underlined here seems more critical. The Court's reasoning implied that Germany was, as a matter of its constitutional law, barred from joining the monetary union, unless all of Europe subscribed to Germany's monetary philosophy.

65 Ch. Joerges, "States without a Market. Comments on the German Constitutional Court's Maastricht-Judgment and a Plea for Interdisciplinary Discourses", NISER Working-Paper, Utrecht, 1996, also at

http://eiop.or.at/eiop/texte/1997-020.htm. Clearly, one has to ask how serious the Court wanted to be taken when imposing these restraints. "Not too literally" is the answer one can infer from the Bundesverfassungsgericht's response to the subsequent complaint against the entry into the third pase of Monetary Union: The competent political institutions can rely on a prerogative in the assessment of the economic and monetary situation. See Entscheidungen des Bundesverfassungsgerichts 97, 350 - Euro.

66 See J.H.H. Weiler, "Does Europe Need a Constitution? Reflections on Demos, Telos and the German Maastricht Decision" in European Law Journal 1 (1995), 219 ff. (also in O. Due, M. Lutter and J. Schwarze, Festschrift für Ulrich Everling, Vol. 2, Baden-Baden 1995, 1651 ff.). 


\section{Christian Joerges}

There is little reason to be proud of the imposition of ordo-liberal concepts on the rest of Europe. There is much more reason to believe that this was only, and at best, a pyrrhic victory. In terms of economic policy and political democracy, the most problematical aspect of the 1992 amendments concern fiscal policy. They seek to ensure a budgetary reasonableness/rationale? not through a political process but through "juridification", namely, the rules laid down in Article 104 and in the Protocol "On the Excessive Deficit Procedure and the Monitoring of these provisions by the European Commission". The replacement of fiscal policy with pre-fabricated, albeit, in many respects, indeterminate rules, mirrors the precarious political legitimacy of the whole construct. Fiscal policy is economic policy. And if it is nevertheless political, some actors, identifiable to the citizen, should be accountable for it. Framework rules and their "implementation" through the European Commission constitute the typical pattern. Wherever Europe needs to organize a policy field in which the legal powers and/or administrative resources at the European level of governance are insufficient, it will (have to) resort to such techniques.

This indicates that the Member States are neither able and nor willing to comply with an institutional compromise, which was born out of the need to find a non-political supranational answer to a policy area which was once a core area of national sovereignty and parliamentary control. Not only Germany, once the self-confident promoter of rule-bound stability, but also France, the Netherlands, and six out of the new Member States are exceeding the 3\% deficit limit. Could it be that the assumptions on which these rules of the Stability Pact builds, are shaky? Barry Eichengreen, an American observer of Europe's monetary policy during the negotiations of the Maastricht Treaty, ${ }^{67}$ holds such an opinion. One of the mild formulae he uses is that the $3 \%$ "numerical threshold is not well grounded in theory" ${ }^{68}$ At times, his language is stronger. ${ }^{69}$ However, he is just one economist among many. What is uncontroversial, however, is the "fact" that there is controversy about the reasonableness/rationale? of the rules that the Member States have signed.

Lawyers are not supposed to examine the reasons, but are supposed to obey authorities, Immanuel Kant once remarked somewhat sarcastically. ${ }^{70}$ In a field so strongly infiltrated by

67 See his "Should the Maastricht Treaty be Saved?" (Princeton studies in international finance no. 74), Princeton, NJ 1992.

68 In his Working Paper PEIF-6 on "Institutions for Fiscal Stability", which he prepared for the Munich Economic Summit of 2-3 May, 2003.

69 A harsher one: the "3 percent ceiling is at best silly and at worst perverse" - which he wrote in a contribution to DIE ZEIT of 20 November 2003.

70 Immanuel Kant, "The Contest of Faculties", in Kant: Political Writings (Hans Reiss, ed., $2^{\text {nd }}$ ed. 1991). 
non-legal expert knowledge and so difficult to programme in advance by sound and stable criteria, there are other reasons for being cautious about taking decisions qua law. ${ }^{71}$ Would institutional actors be well advised not to search for legal answers?

That is a question which the ECJ had to deal with in a recent judgment. ${ }^{72}$ On 27 January 2004, the European Commission had brought an action against the Council of the EU before the ECJ. ${ }^{73}$ The Commission asked the Court to declare inter alia that the (economic and financial affairs) Council's refusal, in its "conclusions" of 25 November 2003, "to adopt the formal instruments contained in the Commission's recommendations pursuant to Article 104(8) and (9) EC ... are unlawful and should be annulled". The Commission had initiated an excessive deficit procedure in relation to Germany in November 2002, and the Council had confirmed, by a decision of 21 January 2003, that an excessive deficit existed. An excessive deficit procedure had also been initiated in relation to France in April 2003 and the existence of an excessive deficit been confirmed by the Council on 3 June 2003. The Commission then recommended the Council on 8 October "to establish that the French Republic had undertaken no effective action", and on 21 October "to decide, under Article 104(9) EC, to give notice to the French Republic to take measures to reduce its deficit"; ${ }^{74}$ Germany was treated likewise. ${ }^{75}$ The Council took a vote on the requests without achieving the majority required in Article 104(13). It also took votes on the Commission's recommendations under Article 104(9) EC. In its conclusions, the Council explained that it had "decided not to act, at this point in time, on the basis of the Commission Recommendation for a Council decision under Article 104(9)" and "agreed" to hold the Excessive Deficit Procedure "in abeyance for the time being". 76

What could one expect the ECJ to do? Go by the books? To be cautious with powerful Member States? ${ }^{77}$ The ECJ did not indicate what it thought about the controversy on the soundness of the Stability Pact. Instead, it underlined the high importance that all institutional

71 M.J. Herdegen, "Price Stability and Budgetary Restraints in the Economic and Monetary Union: The Law as Guardian of Economic Wisdom", Common Market Law Review 35 (1968), 9 ff.

72 On the following cf. R. Streinz, Ch. Ohler and Ch. Herrmann, "Todgesagte leben länger - oder doch nicht? Der Stabilitäts- und Wachstumspakt nach dem Beschluß des Rates vom 25. 11. 2003 über das Ruhen des Defizitverfahrens gegen Frankreich und Deutschland", Neue Juristische Wochenschrift 57 (2004), 1553 ff. and the reconstruction of the events in para.s $7 \mathrm{ff}$. of the ECJ Judgment (Full Court) of 13 July 2004 in Case C27/04 - Commission v. Council (nyr).

73 Case C-27/04; cf., OJ C 354 of 7 February 2004.

74 Case C-27/04, paras. 9-10.

75 Case C-27/04, paras. 11-12.

76 Case C-27/04, para. 20.

77 Cf., the Bundesverfassungsgericht's cautious, if not evasive, response to the "four professors" asking it to examine the legality of the Community's allegedly much too lax application of the Maastricht convergence criteria (see Entscheidungen des Bundesverfassungsgerichts 97, 350 and note 65 supra). 


\section{Christian Joerges}

actors had attached to it. ${ }^{78}$ It observed that it was simply not legally foreseen in the pertinent provisions to hold procedures "in abeyance" and concluded that "the Council's conclusions adopted in respect of the French Republic and the Federal Republic of Germany respectively must ... be annulled in so far as they contain a decision to hold the excessive deficit procedure in abeyance and a decision modifying the recommendations previously adopted by the Council under Article 104(7) EC". ${ }^{79}$ It also underlined, however, that the Council has "a discretion" and that "it may, in particular on the basis of a different assessment of the relevant economic data, of the measures to be taken and of the timetable to be met by the Member State concerned, modify the measure recommended by the Commission..." ${ }^{80}$ Hence, the Commission's "action is inadmissible in so far as it seeks annulment of the Council's failure to adopt the formal instruments contained in the Commission's recommendations pursuant to Article 104(8) and (9) EC". 81

Could the Court have done more? Should it have indicated that the restraints that the Stability Pact imposes on democratically legitimized governments should be reconsidered in the light of Europe's current efforts to address its democracy deficit? It is worth noting that the ECJ exercised more prudence than most of the commentators on the Draft Constitutional Treaty, who simply defended the views which the Maastricht rules had incorporated, and warned against any softening of that discipline. Thus, Paul Kirchhof, co-author of the Maastricht judgment, ${ }^{82}$ wonders whether the expectation, expressed in Article I-29(2), that the Central Bank should support general economic policies in the Union, might weaken its dedication to the price stability objective. ${ }^{83}$ Peter Behrens, in his careful textual analysis, appreciates that the pertinent provisions have not significantly changed. ${ }^{84}$ The widely articulated $^{85}$ concern about the wording of Article 1-3(3) in the Draft Treaty found its resonance: after the amendment by the Intergovernmental Conference of June 2004, "price stability" is now named among the objectives to which that provision assigns constitutional dignity. Can we sleep well again? "The stability pact is dead and gone", ${ }^{86}$ argued Barry

\footnotetext{
Case C-27/04, paras. $67 \mathrm{ff}$.

Case C-27/04, para 97.

Case 27/04, para 80.

1 Case 27/04, para 36

Supra note 63.

P. Kirchhof, “Europa auf dem Weg zu einer Verfassung?”, ZES 2003, 358 ff. at 379.

Supra note 62 (in Section V.4).

85 Most prominently by the ECB: Opinion of the European Central Bank of 19 September 2003 on the draft Treaty establishing a Constitution for Europe (CON/2003/20), para. 8.

86 Hence the title of his contribution in DIE ZEIT (note 69).
} 
Eichengreen at the beginning of the controversy. Compliance with it would further damage the German economy, in particular. This would not be in the European interest. Who knows that? Maybe, we lawyers should not take responsibility for decision-making in which we risk discrediting the law. ${ }^{87}$ The constitutional risk inherent in a misconceived "juridification" of monetary and fiscal policy responsibilities is to create a vacuum in which political actors cannot be held accountable and the very idea of law-mediated legitimacy gets destroyed. ${ }^{88}$ The sad concluding message is that the Maastricht Treaty and the Maastricht judgment were a pyrrhic victory for a twofold reason: (1) Maastricht confirmed the decoupling of the social from the economic constitution thereby deepening Europe's social deficit. (2) Rather than establishing the supremacy of law over monetary and fiscal policy, Maastricht has "dejuridified" the economic constitution - and now it seems that the effort to cure the social deficit has run into the same trap.

\section{Are we About to Bring the Law to Trial? Some Queries with the Open Method of Co-ordination}

What, then, is left of the European Economic Constitution and what is Left of it? If we think about the "l" in small letters, we might conclude: not very much! An abstract normative idea losing ground in conceptual debates and in European political arenas. But when we take a capital letter " $L$ ", a widespread reaction is that there are prospects for a new mode of governance which seems tailored to overcome Europe's social deficit, namely, the Open Method of Co-ordination (OMC).

\section{The Career of the Concept}

Like everything else in this world, the OMC has its precursors. ${ }^{89}$ But it is cum grano salis safe to take the Lisbon Council of 2000 as the birthday of the OMC.$^{90}$ This Council was primarily

87 See M.J. Herdegen, op. cit. (note 73).

88 See F. Snyder, "EMU Revisited: Are we Making a Constitution? What Constitution are we Making?", EUI Working Paper Law 98/6 (abbreviated version in P. Craig/G. de Búrca (eds.), The Evolution of EU Law, Oxford 1999, 417 ff.); M. Everson, "The Constitutional Law of the Euro? Disciplining European Governance", in P. Beaumont and N. Walker (eds.), Legal framework of the Single European Currency, Oxford 1999, $119 \mathrm{ff}$.

89 One could name here the co-ordination of economic policies under Article 99. The Stability Pact is of another quality, however, because it restricts the ways leading to sustainable budgetary policies quite strictly. Much more important, however, is the more general "turn to governance" in the EU (cf. extensively Ch. Joerges, "The Law in the Process of Constitutionalising Europe", EUI Working Paper Law 4/2002 and Ch Joerges and M. Everson, "Law, economics and politics in the constitutionalization of Europe", in E.O. Eriksen, J.E. Fossum and A.J. Menéndez, Developing a Constitution for Europe, London-New York 2004, 162 ff., 173 ff.

90 Http://europa.eu.int/council/off/conclu/mar2000/index.htm. 
dedicated to knowledge society issues and to setting very ambitious goals for Europe in pertinent industries. However, it also renewed the agenda of "social Europe" and tried to turn what, until then, had been perceived as a deficit, namely, the lack of genuine European competences and the unavailability of the traditional "Community method", into a virtue. The OMC, so Jonathan Zeitlin argues, promises to be:

\begin{abstract}
"an attractive model of how a non-coercive form of policy co-ordination emphasizing mutual learning and exchange of good practices could be applied to a politically sensitive field such as social protection which is characterized by wide institutional variations across EU Member States, where harmonization is considered by many to be neither practicable nor desirable". 91
\end{abstract}

A European Employment Strategy was the first objective. Employment is a pressing problem in so many European states. At the European level of governance, it cannot be directly addressed with the means that the Union has at its disposal. But it can be discussed, nonbinding objectives substantiated, and guidelines offered. These recommendations can then be adapted in the Member States to their specific contexts. This type of implementation cannot be subjected to the controls through which the Community seeks to ensure compliance with its legislative frameworks and policies. But the activities at Member State level can be "benchmarked" and evaluated. The accompanying hope is that this will open chances for mutual learning and better performance. ${ }^{92}$

The OMC approach has since been applied to other areas, such as social inclusion and pensions. It has even become something like a Leitbild on the political Left. ${ }^{93}$ It has also attracted much attention in the Convention Process. The final report of Working Group VI on "Economic Governance" stated: "The Working Group considers that the Open Method of Coordination has proved to be a useful instrument in policy areas where no stronger co-ordination

91 J. Zeitlin, "Comments on Jacobsson and Vifell, Employment Policy Co-ordination: Between Deliberation and Discipline?”, Ms. Madison,WI 2004.

92 As was underlined on the Lisbon summit, the OMC procedure is "a fully decentralised approach" which can be applied "in line with the principle of subsidiarity"; the Union, the Member States, the regional and local levels, as well as the social partners and civil society can and should be actively involved, using variable forms of partnership'. Presidency Conclusions, Lisbon European Council, March 23-24, 2000 (http://europa.eu.int/council/off/conclu/mar2000/index.htm).

93 Most prominently: Maria João Rodrigues, Professor at the University of Lisbon and Special Adviser to the Prime Minister, Coordinator of the Lisbon Council (see her edited The New Knowledge Economy in Europe, Cheltenham 2002), and Frank Vandenbroucke, Minister for Employment and Pensions in the Belgian Federal Government; cf., his lecture on "Promoting active welfare states in the EU" at the University Of Wisconsin, Madison of 30 October 2003 (on file with author); see, also, his "Foreword", in G. Esping-Andersen et al. (eds.), Why We Need a New Welfare State, Oxford 2003, viii-xxiv. 
instrument exists." 94 Such positive evaluations were shared by other Working Groups. The quest for "constitutionalization" through the Constitutional Treaty was but a logical step."

There has never been unanimity, however, in the evaluation of the OMC within the Convention or elsewhere. Milena Büchs,${ }^{96}$ in a comprehensive and particularly thoughtful analysis of pertinent debates, distinguishes between three types of issues: (1) one concerns the efficacy of the OMC. What made Working Group VI believe that the OMC had proved to be a useful instrument? (2) Such primarily empirical enquiries are complemented by analyses of the relations between the political structures of the EU, the dilemmas of European social policy and the search for explanations of why the OMC may overcome, or fail to overcome, these impasses. (3) The third debate concerns the legitimacy of the OMC in both senses of this term: will the OMC find acceptance, e.g., because of the beneficial outcome it generates for the majority of Europeans? Do the OMC practices deserve recognition because they strengthen democracy and enhance the normative quality of EU governance?

\section{Output Legitimacy? ${ }^{97}$}

Uncertainty about the effects of the OMC is unsurprising and statements which present it as something like a Wunderwaffe that will win the battle against Europe's social model are not to taken literally. David M. Trubek, however, one of the Method's most eloquent exponents, stresses that we should understand the emergence of the OMC as a potentially workable

94 CONV 516/1/03 Working Group XI on Social Europe: 18, 19; cf., “Tomorrow Europe”, July 2003, no. 17, at 3: "Those opposed to including such a reference had advanced three sets of arguments: the fear of incorporating an intergovernmental method liable to compromise the definition of hard-won competences; a lack of transparency and democratic control; but also a lack of legitimacy owing to the involvement of a large number of experts in the process".

95

See G. de Búrca and J. Zeitlin, "Constitutionalizing the Open Method of Co-ordination. A Note for the Convention", Florence-Madison, WI 2002; Ch.F. Sabel and J. Zeitlin, "Networked Governance and Pragmatic Constitutionalism: The New Transformation of Europe", New York-Madison,WI 2003. See http://eucenter.wisc.edu/OMC/index.htm .

96 "Dilemmas of the post-regulatory approach for European social policy", Ms. Berlin 2004.- - Are the Germans taking a Sonderweg in the assessment of the OMC?

97 The distinction between output and input legitimacy is as widely used as it is problematic (see B. Peters, "Public Discourse, Identity, and the Problem of Democratic Legitimacy", in E.O. Eriksen (ed.), Making the Euro-Polity. Reflexive Integration in Europe. London (forthcoming). The use in the text refers to distinctions between objections against the efficacy of the method and its recognition as a legitimate alternative to lawbound governance. For a strong critique of output-oriented defences of the OMC cf. A. Schäfer, Zwischen internationalen Zielen und nationaler Politik: wirtschaftspolitische Koordinierung in der Europäischen Union, der OECD und dem internationalen Währungsfonds, Frankfurt a.M.(forthcoming). He insists that we should first seek to explain why and in which institutional and political context OMC was adopted and argues that the softness of the Method reflects the divergence of national views and strategies as well as the unwillingness to commit national systems to policy changes. In his analysis, OMC complements the turn from Keynesianism to Monetarism as institutionalized in the harder Monetary Union and the Stability Pact, it thus confirms the old schism between the welfare state(s) and economic integration. 
response to the dilemmas of national welfare state politics, and design our research agendas accordingly. We should analyse its potential to "re-calibrate" social policies in a more flexible, participatory, experimental mode and to accomplish this objective as a multi-level governance system. ${ }^{98}$ The $\mathrm{OMC}$, we read in a recent paper, will "create transnational expertise networks that: transmit new ways of thinking about social policy across borders; broaden participation in such transnational policy networks to ensure legitimacy and effectiveness; merge technical insight with practical knowledge and new normative visions; combine a problem-solving technical approach with participatory deliberation; facilitate lower level experiments; produce learning through decentralized experimentation, wide-spread bench-marking, exchange of best practices, and peer review; bring various policy worlds together; foster public-private cooperation; and avoid a race to the bottom via multi-lateral surveillance and shaming", adding , however, that such claims must be "subjected to rigorous testing". 99

\section{Normative Queries}

It is difficult not to agree with such an understanding of the OMC. And yet, we must consider the risks that we run once this machinery is set in motion. This is, in particular, Claus Offe's disquieting objection: ${ }^{100}$ The OMC has effects, but not the promised ones. It will instead destroy the non-Anglo-Saxon modes of welfarism in Europe. How should the Law know? But it is by no means exceptional for lawyers and law to be confronted with contests over issues they do not understand and with uncertainties over the implications of their decisions. They should, therefore, understand their task of designing responses to such difficulties. The OMC is an institution designed to find, not to implement, solutions. Is it a good design?

98 D.M Trubek and J. Mosher, "New Governance, EU Employment Policy, and the European Social Model", in Ch. Joerges, Y. Mény and J.H.H. Weiler (eds.), Mountain or Molehill?, Symposium on the Commission White Paper on Governance, New York University School of Law 2001, accessible at www.iue.it/RSC/etexts/WPgovernance.pdf/ [also in J. Zeitlin and D. Trubek (eds), Governing Work and Welfare in a New economy: American and European Experiences, Oxford 2003, 51 ff.]; D.M. Trubek and L. Trubek, "Hard and Soft Law in the Construction of Social Europe: the Role of the Open Method of Co-ordination", Center for World Affairs and the Global Economy, European Union Center and Law School, University of WisconsinMadison 2004.

99 Not so rigorous but with some reserves: B. Bercusson, "Social Rights in the European Constitution", Ms. London 2004: "It remains to be seen whether the OMC, hitherto criticised as to its effectiveness when implemented by Member States' administrations in the field of employment policy, is appropriate for the Work Programme of the Social Partners on Employment. If joint opinions and other non-regulatory instruments continue to be ineffective, their failure may imply other, more rigorous steps towards effectiveness, including regulatory agreements and/or legislation" (at 21).

100 Note 7; similarly, D Chalmers and M. Lodge, The Open Method of Co-ordination and the European Welfare State ESCR Discussion Paper 11, London (LSE) 2003. 


\subsection{Democratic Experimentalism?}

The theoretical background on which the advocates of the OMC rely has been developed outside European frameworks. ${ }^{101}$ The have then be tried out in American administrative law, ${ }^{102}$ before they were presented in Europe ${ }^{103}$ and the merger with OMC occurred. ${ }^{104}$

It is important to remember that the whole approach of democratic experimentalism received its inspirations from a societal sphere, which European constitutionalism tends to treat with (un)benign neglect, namely, the organizational practices of private business. In a daring and fascinating move, ${ }^{105}$ Charles Sabel and his followers have applied the lessons to be learnt from the Japanese variety of capitalism about their practices of benchmarking, the need to adapt to incessant change, ${ }^{106}$ the commitment to permanent experimentation, an interest and a readiness in mutual learning from independent monitoring, the establishment of systems of measurement and evaluation, etc., to administrative bodies, and argued that their regulatory practices should follow these examples from economy and society. Democratic experimentalists promise that "a successful institutionalization of the principles of benchmarking, simultaneous engineering, and independent monitoring allows us to tackle volatility and diversity best" - not just within firms. ${ }^{107}$

At first sight, this message might look like a strange loop which begins in the public sphere, then goes into the private realm, and then brings messages from there to its point of

101 Cf., the reconstruction by W.E. Scheuerman, "Democratic Experimentalism or Capitalist Synchronization? Critical Reflections on Directly-Deliberative Polyarchy", Canadian Journal of Law and Jurisprudence 17 (2004), 101-127, 108 ff.; cf. earlier Ch.F. Sabel, "Bootstrapping Reform: Rebuilding Firms, the Welfare State, and Unions" Pol. \& Soc. 23 (1995), 5 ff.; J. Cohen and Ch.F. Sabel, Sovereignty and Solidarity: EU and US", in J. Zeitlin and D.M. Trubek (eds.), Governing Work and Welfare in a New Economy: European and American Experiments, Oxford 2003, 345-375.

102 M.C. Dorf and Ch.F. Sabel, “A Constitution of Democratic Experimentalism”, Colum. L. Rev. 98 (1998)267 ff.

103 J. Cohen and Ch.F. Sabel, "Directly-Deliberative Polyarchy", European Law Journal 3 (1997), $313 \mathrm{ff}$.

${ }^{104}$ Cf., J. Scott and D.M. Trubek, Mind the Gap: Law and New Approaches to Governance in the European Union, European Law Journal 8 (2002), 1-18O. Gerstenberg and Ch.F. Sabel, Directly-Deliberative Polyarchy, An Institutional Ideal for Europe?, in Ch. Joerges and R. Dehousse (eds.), Good Governance in Europe's Integrated Market, Oxford 2002, 289-341; J. Zeitlin and D.M. Trubek (eds.), Governing Work and Welfare in a New Economy: European and American Experiments, Oxford-New York 2003.

105 See, in particular, Ch.F. Sabel, "Learning By Monitoring: The Institutions of Economic Development" in N. Smelser and R. Swedberg (eds.), The Handbook of Economic Sociology, Princeton, NJ 1994, 137 ff.

106 "High-speed capitalism" is the category Scheuerman uses referring to David Harvey, Justice, Nature and the Geography of Difference, Oxford 1996) when explaining his own analytical basis and normative perspectives; see, also, W.E. Scheuerman, "Reflexive Law and the Challenges of Globalization", J. Pol. Phil. 9 (2001), 81 ff.

107 W.E. Scheuerman (note 105), at 111. See O. Gerstenberg, "Law's Polyarchy: A Comment on Cohen and Sabel” European Law Journal 3 (1997), 343 ff.; also, R. Schmalz-Bruns, "Deliberativer Supranationalismus. Demokratisches Regieren jenseits des Nationalstaats" Zeitschrift für Internationale Beziehungen 6 (1999), 185 ff., at 236-38. 
departure. Have we not all been taught to use all sorts of legal instruments - company law, antitrust, and economic regulation - to tame private enterprise? Why is there such a widely felt need to extend the reach of fundamental rights into the private sphere if private governance develops superior qualities, anyway? Are all the quests for a constitutionalization of the subconstitutional spheres of the legal system and the search for a "societal constitutionalism" superfluous. ${ }^{108}$ In an ironic sense, democratic experimentalism can be called a methodological heir to first generation Ordo-liberalism. It invokes qualities inherent in the economic sphere as a yardstick that public governance should respect and internalize; and the affinities with the Hayekian discovery procedure may seem even stronger because von Hayek has substituted the strong state of the ordo-liberals by the smoother governance of general legal rules. ${ }^{109}$ These affinities are, however, very limited. Whereas Ordo-liberalism sought to protect the ordo of the economy through a strong state which would rigorously enforce laws against restrictive business practices and abuse of private power, democratic experimentalism is relying on political processes, softer modes of co-ordination and the subtle power of transparency and exposure to public critique. And, in contrast to the Hayekian discovery process, the proposals to "institutionalize" democratic experimentalism invoke the imagination not just of entrepreneurs and market participants but also of deliberating political citizens, and trust in their readiness to engage in problem-solving and in their interest to learn from one another.

"Sweet melodies", to be sure. The question, however, of whether we should listen to them and trust "a law so 'soft' to be no law at all"? ${ }^{110}$ This soft supranational power may not be so innocent, opines Alexander Somek. The "new modes of governance", he observes, "are marked by two characteristics: first, they are informal in that they are based on informationgathering, the drawing up of 'action-plans', the allocation of public praise for 'best practice' and the shaming of under-achievers; second, even though they have been designed for special policy areas, they are nonetheless 'holistic', which means, in the words of the European Commission, that they commit 'Governments as a whole, as well as a wide range of stakeholders'. A diffuse soft power is exercising its hold without being constrained by the norms which govern competence allocation. ${ }^{111}$ Similar concerns have been articulated by Marc

108 On this notion, see note 6 supra.

${ }^{109}$ See, for a systematic analysis, H.-G. Graf, “Muster-Voraussagen "und Erklärungen des Prinzips” bei F.A. von Hayek, Tübingen 1978; M. Amstutz, Evolutorisches Wirtschaftsrecht, Baden-Baden 2001, 30 ff., 219 ff.; Ch. Mantzavinos, "Das institutionenökonomisch-evolutionäre Wettbewerbsleitbild", Preprints des Max-PlanckInstituts für öffentliche Güter, Bonn 2004/1.

110 M. Everson, "The Constitutional Law of the Euro?" (note 88), 120.

111 A. Somek, "The age of constitutional law. Decline and fall of an empowering idea", Ms. Iowa 2004, 9. 
Amstutz on a systems theory basis. His concern is the law's proprium, namely, its function and task to respond to conflicts which cannot be resolved in the societal sub-systems in which they originate. ${ }^{112}$ In a discourse theory version, what may function at the level of local "government councils" will be much more difficult to achieve when experimentalists meet with national, European and international standardization bodies, ${ }^{113}$ or face administrators who are keen to promote the institutional prestige and power of their organisations, or welfare bureaucracies which seek to defend their own practices and/or the political interests of their superiors. Can we really believe that arrangements will be found, implemented and sustained, in which stakeholders engage with sufficient intensity and continuity in the definition and discussion of their concerns so that legitimacy can be said to rest on the deliberative processes of all the affected parties. Democratic experimentalism asks us to take the traditional virtues of the rule of law lightly. It asks us to loosen the ties between law and enforcement, and, instead, to trust that our societies will manage with much less governmental powers. But it does not tell us how we might find the post-national criteria that will enable and legitimate a "benchmarking" of national experiences, histories, and aspirations. It fails to explain how the insights that the exposure to the experiences of others might lead to co-ordinated policies and how they might be implemented against unconvinced opponents. More importantly, it fails to address the risks that its own implementation in the EU entails. There is nothing wrong with bureaucracies and experts exchanging experiences and learning about new possibilities. There is a great deal wrong with building up opaque networks which get entrusted with the task of seeking to carry through what they have learned or agreed upon in democratic societies. Such a model of governance may be soft because it no longer relies on mandatory provisions. It is, for the same reason, strong because it risks empowering the executive and removing the virtues of democratic accountability, of rule-bound public governance and its judicial control. ${ }^{114}$ Should

112 M. Amstutz, "Zwischenwelten. Zur Emergenz einer interlegalen Rechtsmethodik im europäischen Privatrecht", in Ch. Joerges and G. Teubner (eds.), Rechtsverfassungsrecht, Recht-Fertigung zwischen Privatrechtsdogmatik und Gesellschaftstheorie, Baden-Baden 2003.

113 An interesting exception is the interpretation of the "New Approach" offered by J. Scott, "International Trade and Environmental Governance: Relating Rules (and Standards) in the EU and the WTO", European Journal of International Law 15 (2004), $307 \mathrm{ff}$.

114 Similar objections have been raised by democratic experimentalists, and, in a similar vein by E.-J. Mestmäcker ["Wandlungen in der Verfasstheit der europäischen Gemeinschaft", in idem, Wirtschaft und Verfassung (note 46), 49 ff., 69 ff.] against comitology and the idea of "deliberative supranationalism" as defended by this writer. Why the OMC should be a democratically superior mode of governance than comitology is difficult to understand. Comitology operates in much narrower and better defined realms. Its social and legal embeddedness is more intense. Its successful "constitutionalization" is imperfect but seems at least conceivable; cf., Ch. Joerges, “Comitology and the European model?' Towards a Recht-Fertigungs-Recht in the Europeanisation Process", in E.O. Eriksen, Ch. Joerges and J. Neyer (eds.), European Governance, Deliberation and the Quest for Democratisation, EUI-RSCA/Arena (Arena Report 2/2003. Oslo), $501 \mathrm{ff}$. 
we, by taking the rule of law so lightly, promote but executive governance instead of deliberate polyarchy?

W.E. Scheuerman has complemented these sceptical queries by a sociological observation. He summarizes one key assumption of democratic experimentalism as the assertion "that we increasingly encounter evidence of diversity in terms of local conditions and regulatory needs". He confronts this claim with the tendencies of "high-speed" capitalism "to compress and even 'annihilate' geographical space or distance. High-speed social activity dramatically heightens the possibilities for interaction across both geographical and the existing political divides, opening the door to historically unprecedented opportunities for simultaneity and instantaneousness in human experience". ${ }^{115}$ Democratic experimentalists, he continues, fail "to provide an adequate place in their theory, in both normative and institutional terms, for those facets of contemporary social experience poorly captured by its repeated references to local diversity in social conditions". ${ }^{116}$

\subsection{Bringing the Eighties Back In?}

The turn to soft governance in the EU and the turn away from the very idea of law-mediated governance are risky. And it seems that this risk is not really necessary. It may be an all too hasty disregard of the alternatives that were elaborated decades ago. The intense debates of the 1970s about the failures of welfare-state juridification strategies were guided by normative concerns about the intrusion of bureaucratic machineries into the economy and the life-world. It was the broadly experienced disappointment with "purposive" legal programmes and a new sensitivity towards "intrusions into the life-world" through a juridification of social policy goals that triggered the search for models of legal rationality that would fill the gaps left open by formalist legal techniques, and, at the same time, cure the failures of the law's grip on social reality on the basis of some "grand theory" (such as economic theories of law, systems theory or discourse theories). ${ }^{117}$ "Proceduralisation" and "reflexive law" were, at the same time,

\footnotetext{
115 "Democratic Experimentalism" (note 101), $119 \mathrm{ff}$.

116 Ibid., 120.

117 See G. Teubner, "Substantive and Reflexive Elements in Modern Law", Law and Society Review 17 (1983), 239-285; R. Wiethölter, "Materialisation and Proceduralisation of Law", in G. Teubner (ed,), Dilemmas of Law in the Welfare State, Berlin-New York 1986, 221 ff.; "Proceduralisation of the Category of Law", in Ch. Joerges and D.M. Trubek (eds.), Critical Legal Thought: An American-German Debate, Baden-Baden, 1989, 501 ff.; J. Habermas, Between Facts and Norms, Cambridge, MA 1999427 ff; idem., "Paradigms of Law", in M. Rosenfeld and A. Arato (eds.) On Law and Democracy: Critical Exchanges, Berkeley-Los Angeles, CA, 13 ff. Earlier German contributions include R. Wiethölter, "Entwicklung des Rechtsbegriffs", in V. Gessner and G. Winter (eds.), Rechtsformen der Verflechtung von Staat und Wirtschaft, Opladen 1982, 82 ff; Ch.
} 
concerned with very practical matters, namely, the problems of implementation and compliance. Discrepancies between legal programmes - especially between "purposive" legislation designed to achieve specific objectives and the actual impact of such laws on society - were a core concern of legal sociology, of effectiveness and implementation research. ${ }^{118}$ The normative and the pragmatic critique of purposive programmes and of command-and-control regulation have motivated a search for alternatives such as selfregulation and soft law. Such strategies responded to the same concerns that the proponents of the OMC now invoke. But they sought to keep the rule of law alive.

\section{A Resumé}

So much for the critique. And what has the critic to offer instead? The law is a normative exercise; the whole discipline is engaged in the production of valid answers which distinguish between the legal and the illegal, and equate this distinction with justice as opposed to injustice. Ambivalent messages are not particularly welcome and are difficult to endure.

And yet, the uncertainties of the state of the (European) Union may require exactly that - at least, if lawyers seek to take up the three issues denoted in the introduction: ${ }^{119}$ Does the constitutionalization of Europe reach out into the "Economy and Society"? Are there alternatives to the OMC alternative to the exhausted economic constitution? Can we ensure that European governance remains rule-bound and its legitimacy continues to be meditated by law?

\section{The Constitutional Treaty}

The obvious first object is to look for answers to these questions in the new Constitutional Treaty as amended on 22 June $2004,{ }^{120}$ in particular, in the provisions that prmise to reach out into "Economy and Society": the "social market economy" has become a constitutional objective, ${ }^{121}$ and access to services of general economic interest is recognised and respected ${ }^{122}$

Joerges and G. Brüggemeier (eds.), Workshop zu Konzepten des postinterventionistischen Rechts, Zentrum für Europäische Rechtspolitik, Materialien 4, Bremen 1984, 25-64.

118 Famously summarised and analysed by G. Teubner, "Juridification - Concepts, Aspects, Limits, Solutions", in idem (ed.), Juridification of Social Spheres, Berlin-New York 1987, 3 ff.

119 Section I, text accompanying notes $4 \mathrm{ff}$.

120 Note 37.

121 According to Article 1-3 (3) CT the "Union shall work for ... a highly competitive social market economy".

122 Article II-36; this is an important signal, because it confirms the right of Member States to pursue distributional objectives. The compatibility of such policies with the opening of national or regional markets to "foreign" competitors is a complex issue of constitutional importance. It is one of the many fields where "constitutionalisation" has to occur incrementally. 
by Article II-36, which incorporates the new "social rights". ${ }^{123}$ Last but not least, elements of the OMC can be seen in various places. ${ }^{124}$ We find a first reference in Article I-1(4) which states: "the Union may adopt initiatives to ensure the co-ordination of the Member States' social policies"; Part III (Policies and Functions) refers to the OMC four times, once in the section on Social Policy (Article III-107), and once in Chapter V Section 1, on Public Health (Article III-179). ${ }^{125}$

Most of these topics have already been mentioned and those not mentioned are too big to be dealt with en passant. Suffice it to restate here that the invocation of the "social market economy" in the Constitutional Treaty is conceptually flawed, and is, politically, an all too risky promise, because it may raise expectations which it will subsequently fail to deliver. Instead of saying "flawed", one might also say "empty": the historical compromise that the concept once embodied is no longer alive. Not even the ordo-liberal component of this legacy was present in the deliberations of the Convention. However, one linguistic detail does deserve a particular mention here: "Ordnungspolitik" was the German name of Working Group VI. The English name was "economic governance". Was this an innovative translation? Not really. It was the Convention Secretariat who was responsible for the introduction of the term, in which someone remembered the fierce controversies between "Ordnungspolitik" and "industrial policy" in the Maastricht Intergovernmental Conference. A case of "linguistic-discursive pathdependency", according to Andreas Maurer, ${ }^{126}$ which became definite when Joschka Fischer and Dominique de Villepin submitted a common position on Ordnungspolitik just before Christmas 2002, ${ }^{127}$ after/when Working Group VI had already closed its files. ${ }^{128}$

Will the "social rights" serve as an Ersatz? The easy answer is that this is difficult to predict and that we should wait and see what the ECJ tells us. This answer sounds easy but is not trivial. It is not trivial because it implies that we, the citizens, should entrust the Court with

123 The Rights' Charter as solemnly declared in Nice was incorporated into the Constitutional Treaty which now contains social rights especially in Title IV on solidarity.

124 Article I-14 (4): "the Union may adopt initiatives to ensure co-ordination of Member States' social policies"; Part III, section on Social Policy (Article III-107 CDT), on Public Health (Article III-179 CDT). The assignment of a competence "to promote and co-ordinate the economic and employment policies of the Member States" has been repealed. Article I-11(3) as amended on 22 June 2004 (note 37) reads: "The Member States shall co-ordinate their economic and employment policies..."

125 See the following section.

${ }^{126}$ In a letter to the author; A. Maurer is Head of the Research Group on European Integration of the German Institute for International and Security Affairs in Berlin.

127 CONV 470/02.

128 A detail, but a noteworthy one after decades of disagreement between the German proponents of Ordnungspolitik on the one hand, and the French defenders of planification on the other. 
the shaping of a "social Europe". Should the Court take over where the citizens' representatives in the Convention and elsewhere failed to produce clear constitutional guidance? These are puzzling and, to a certain extent, worrying consequences, which are hardly reconcilable with the inherited notions of democracy and of the normative weight of constitutional norms. In addition, we have to assume that the Constitutional Treaty could serve as a sufficiently stable basis for daring activism. This is a somewhat heroic assumption with regard to the social rights in the light of Article II-52 (5) which provides:

"The provisions of this Charter which contain principles may be implemented by legislative and executive acts taken by Institutions and bodies of the Union, and by acts of Member States when they are implementing Union law, in the exercise of their respective powers. They shall be judicially cognisable only in the interpretation of such acts and in the ruling on their legality". 129

\section{Constitutionalization as Process}

"L'éssentiel est invisible pour les yeux", is comfort that Antoine de Saint Exupéry's Petit Prince give us. What is not so visible, because it seems so unexciting and trivial, is the performance of the European machinery, the innumerable, small and not so small, indicators of good European governance. Europeanization is an instigator of countless innovative projects. Directly behind or lying in the shadow of grand designs, such as that of the theory of the economic constitution or directly-deliberative polyarchy, there is another Europe at work. It is not so easy to discover, not so coherent, and often ambivalent. But we can approach it in three steps: (1) one is analytical and interdisciplinary. We have some well-discussed and elaborated hypotheses about the structures of the European multi-level system of governance and the conceptualisation of this system in legal categories; (2) the second step concerns our experiences with and insights into the Europeanization processes. Nobody can claim to know and understand the complex processes of Europeanization in their entirety. But if one studies some of them in some depth, one will discover patterns of change in both successful learning processes and in failures. ${ }^{130}$ The "law of the European economy" which becomes visible in such endeavours is very different - and much more interesting - than the law in the books.

${ }^{129}$ See G. de Búrca, "Fundamental rights and Citizenship", in B. de Witte, 10 Reflections on the Constitutional Treaty for Europe, RSCAS 2003, 11 ff., $22 \mathrm{ff}$.

${ }^{130}$ I refrain from an effort to elaborate the following remarks in the abstract. They need to be substantiated and concretized in the context of much more detailed analyses of specific fields. For a recent attempt cf. Ch. Joerges, "The Challenges of Europeanization in the Realm of Private Law: A Plea for a New Legal Discipline", forthcoming in Duke Journal for Comparative and International Law. 
Europeanization functions as an instigator of change and learning. It is an exercise in transformation, and modernization; (3) there is a theoretical background to this kind of cautious optimism. One, underestimated, virtue of law is its concreteness, the need to take decisions and give reasons for them to actors, litigants, experts and to the wider public; the chance/opportunity and, indeed, duty to reconsider what once seemed settled. Law is a Product guided by reasoning, it is Recht-Fertigung which reflects the justice and fairness of its production processes. ${ }^{131}$ In such perspectives, "constitutionalization" can be conceived not as merely being the writing of a text and its formal acceptance by those who govern us and/or us the people.

Can we expect "constitutionalization as process" not only to ensure the compatibility of open markets with regulatory concerns and preserve the social dimension of private law, but also to overcome Europe's social deficit? This seems highly unlikely but is not unconceivable. "All political projects are inherently unrealistic, in that they strive for a not yet realized objective". This was Wolfgang Streeck's response ${ }^{132}$ to the lecture which Jürgen Habermas delivered in Hamburg on 26 June 2001. ${ }^{133}$ The philosopher argued that a European constitution could help to defend the "European social model". Streeck substantiated his response: too much voluntarism will downgrade a project to mere wishful thinking. This is why it should be accompanied by empirical research. And, at some point, we should be prepared to take the discrepancies which we find between our aspirations and our observations seriously. But when and how? "Constitutionalization as process" is no answer to these questions. Nevertheless, it is a response to the state of the integration project which seeks to take the core idea of constitutionalism seriously.

${ }^{131}$ Cf., R. Wiethölter, "Recht-Fertigungen eines Gesellschafts-Rechts", in Ch. Joerges and G. Teubner (eds.), Rechtsverfassungsrecht. Recht-Fertigung zwischen Privatrechtsdogmatik und Gesellschaftstheorie, BadenBaden 2004, 13 ff.; cf., the analysis by G. Teubner, "Dealing with Paradoxes of Law: Derrida, Luhmann, Wiethölter", in O. Perez and G. Teubner (eds.), On Paradoxes and Self-reference in Law (forthcoming 2004).

132 “Das 'soziale Europa' und seine Verfassung: Fragen zu einem politischen Projekt”, Ms. Cologne 2001. The paper has not been published. But W. Streeck has explained his position more comprehensively elsewhere. Cf., e.g., "From Market-Making to State-Building? Reflections on the Political Economy of European Social Policy", in Stephan Leibfried and Paul Pierson (eds.), European Social Policy: Between Fragmentation and Integration, Washington, DC 1995, 389 ff. : "The Internationalization of Industrial Relations in Europe: Prospects and Problems", Politics and Society 26 (1998), $429 \mathrm{ff}$.

133 "Warum braucht Europa eine Verfassung? Nur als politisches Gemeinwesen kann der Kontinent seine in Gefahr geratene Kultur und Lebensform verteidigen", first published in DIE ZEIT of 29 Juni 2001, reprinted in J. Habermas, Zeit der Übergänge, Frankfurt a.M. 2001, 104 ff.; English translation ("Why Europe Needs a Constitution") in E.O. Eriksen, J.E. Fossum and J. Menéndez (eds.), Developing a Constitution for Europe, London 2004, 19-34. 